\title{
KUALITAS PELAYANAN PUBLIK
}

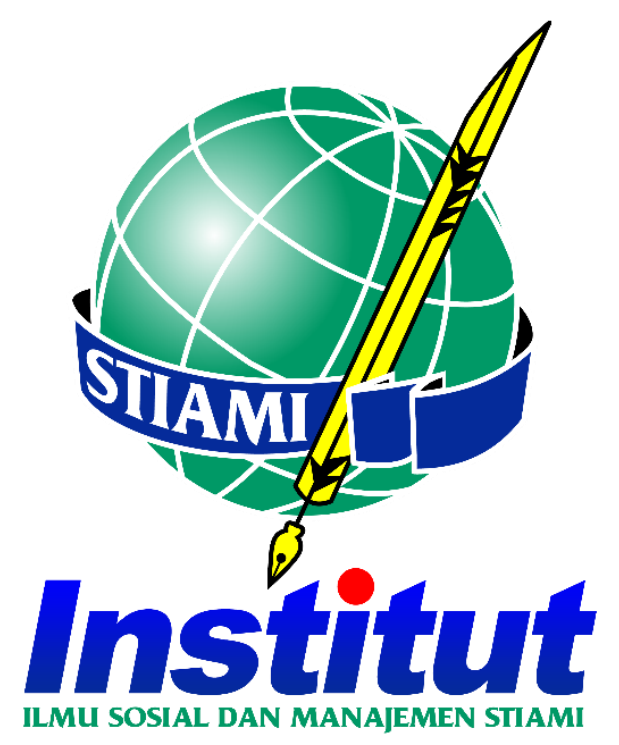

TUGAS MAKALAH

Disusun untuk memenuhi tugas mata kuliah Manajemen Pelayanan Publik

Disusun oleh:

ADE SURIANI - CA116111102

NOLANDA ADYTHYA - CA417111231

FAKULTAS ILMU ADMINISTRASI

PROGRAM STUDI ADMINISTRASI PUBLIK

INSTITUT ILMU SOSIAL DAN MANAJEMEN STIAMI 


\section{KATA PENGANTAR}

Syukur Alhamdulillah kami panjatkan puji syukur atas kehadirat Allah SWT, atas segala limpahan rahmat dan karunia-Nya kepada kami sehingga dapat menyelesaikan makalah ini guna memenuhi tugas kelompok untuk mata kuliah Manajemen Pelayanan Publik dengan judul "Kualitas Pelayanan".

Kami menyadari bahwa didalam proses penulisan makalah ini masih jauh dari kesempurnaan baik materi maupun cara penulisannya, namun kami telah berupaya dengan segala kemampuan dan pengetahuan yang dimiliki sehingga dapat menyelesaikan tugas ini. Oleh karena itu, kritik dan saran dari semua pihak yang bersifat membangun selalu kami harapkan untuk melengkapi segala kekurangan dan kesalahan dari makalah ini.

Akhirnya kami berharap makalah ini dapat bermanfaat untuk menambah pengetahuan terutama bagi pembaca dan bagi penulis khususnya.

Jakarta, 14 Maret 2020

Kelompok 9 


\section{DAFTAR ISI}

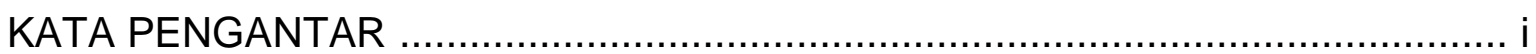

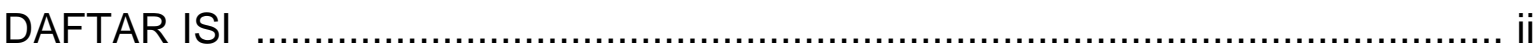

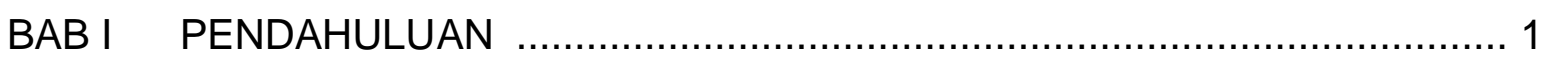

A. Latar Belakang …............................................................... 1

B. Ruang Lingkup Penulisan ...................................................... 2

C. Tujuan Penulisan ............................................................... 2

D. Manfaat Penulisan ............................................................... 2

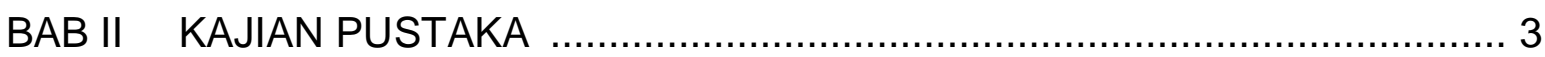

A. Pengertian Kualitas Pelayanan Publik ........................................... 3

B. Dimensi Kualitas Pelayanan Publik ............................................... 6

C. Unsur Kualitas Pelayanan Publik .................................................. 7

D. Faktor Kualitas Pelayanan Publik ............................................... 8

E. Penilaian Kualitas Pelayanan Publik .......................................... 8

F. Manfaat Kualitas Pelayanan Publik ............................................. 9

BAB III PERMASALAHAN DAN PEMBAHASAN ..........................................10

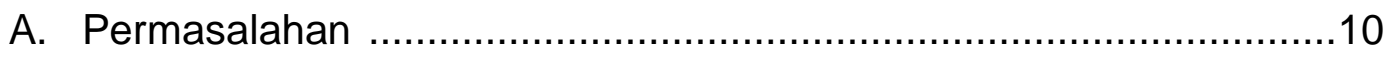

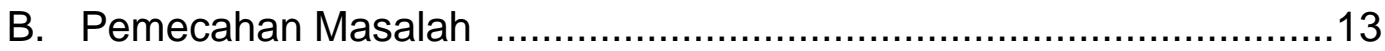

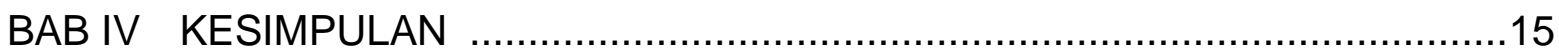

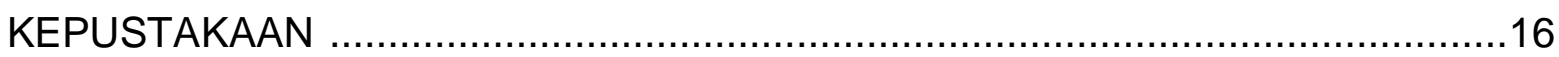




\section{BAB I}

\section{PENDAHULUAN}

\section{A. Latar Belakang}

Pelayanan publik oleh aparatur negara dewasa ini masih banyak dijumpai kelemahan sehingga belum dapat memenuhi kualitas yang diharapkan masyarakat. Hal ini ditandai dengan masih adanya berbagai keluhan masyarakat yang disampaikan melalui media massa, sehingga dapat menimbulkan citra yang kurang baik terhadap aparatur negara. Mengingat fungsi utama pemerintah adalah melayani masyarakat maka pemerintah perlu terus berupaya meningkatkan kualitas pelayanan.

Berbagai kebijakan telah dikeluarkan oleh pemerintah dalam rangka peningkatan kualitas pelayanan publik. Untuk melaksanakan kebijakan tersebut, maka kesiapan dan kemampuan aparatur, baik di tingkat pusat maupun tingkat daerah, perlu ditingkatkan, agar tidak timbul kesenjangan antara tuntutan masyarakat dengan kesiapan dan kemampuan aparatur dalam pelaksanaan fungsi pelayanan.

Pelayanan publik hampir secara otomatis membentuk citra (image) tentang kinerja birokrasi, karena kebijakan negara yang menyangkut pelayanan publik tidak lepas dari birokrasi. Sehubungan dengan itu, kinerja birokrasi secara langsung berkaitan dengan masalah kualitas pelayanan yang diberikan oleh aparatur. Pemberian palayanan yang memenuhi standar yang telah ditetapkan memang menjadi bagian yang perlu dicermati, saat ini masih sering dirasakan bahwa kualitas pelayanan minimum sekalipun masih jauh dari harapan masyarakat dan masyarakat hampir sama sekali tidak memahami secara pasti tentang pelayanan yang seharusnya diterima dan sesuai dengan prosedur pelayanan yang baku oleh pemerintah. Maka dari itu birokrasi pemerintah atau aparatur negara dalam penyelenggaraan pemerintah dan pembangunan memiliki posisi dan peran strategis dalam pelaksanaan pembangunan di suatu negara. Oleh sebab itu, produktivitas maupun efektivitas dan efesiensi organisasi negara atau pemerintah amat tergantung pada aparatur negara. 
B. Ruang Lingkup Penulisan

Untuk memperjelas masalah yang akan dibahas dan agar tidak terjadi pembahasan yang meluas atau menyimpang, maka ruang lingkup permasalahan yang akan dibahas dalam penulisan makalah ini yaitu hanya pada lingkup seputar kualitas pelayanan dalam sektor publik.

C. Tujuan Penulisan

Adapun tujuan penulisan makalah ini adalah:

1. Untuk mengetahui pengertian kualitas pelayanan publik

2. Untuk mengetahui dimensi kualitas pelayanan publik

3. Untuk mengetahui unsur kualitas pelayanan publik

4. Untuk mengetahui faktor kualitas pelayanan publik

5. Untuk mengetahui penilaian kualitas pelayanan publik

6. Untuk mengetahui manfaat kualitas pelayanan publik

7. Untuk mengetahui permasalahan kualitas pelayanan publik

8. Untuk mengetahui pemecahan masalah kualitas pelayanan publik

D. Manfaat Penulisan

Adapun manfaat penulisan makalah ini adalah:

1. Bagi penulis

Diharapkan dapat mendapatkan wawasan dan pengetahuan baru serta dapat mengembangkan ilmu tentang kualitas pelayanan publik melalui pengalaman yang diperoleh selama melakukan penelitian.

2. Bagi pihak lain

Penelitian ini diharapkan dapat menambah pengetahuan dan sebagai refrensi bagi semua pihak nantinya dalam melakukan penelitian kedepan. 


\section{BAB II}

\section{KAJIAN PUSTAKA}

A. Pengertian Kualitas Pelayanan Publik

Dalam Undang-undang No. 25 tahun 2009 tentang pelayanan publik, mendefinisikan bahwa pelayanan publik adalah kegiatan atau serangkaian kegiatan dalam rangka pemenuhan kebutuhan pelayanan sesuai dengan peraturan perundang-undangan bagi setiap warga negara dan penduduk atas barang, jasa, dan atau pelayanan administratif yang disediakan oleh penyelenggara pelayanan publik.

Pemerintahan negara pada hakikatnya menyelenggarakan dua jenis fungsi utama, yaitu fungsi pengaturan dan fungsi pelayanan. Fungsi pengaturan biasanya dikaitkan dengan hakikat negara modern sebagai suatu negara hukum (legal state), sedangkan fungsi pelayanan dikaitkan dengan hakikat negara sebagai suatu negara kesejahteraan (welfare state). Kedua fungsi ini menyangkut semua segi kehidupan dan penghidupan bermasyarakat, berbangsa dan bernegara, dan pelaksanaanya dipercayakan kepada aparatur negara tertentu yang secara fungsional bertanggungjawab atas bidang bidang tertentu kedua fungsi tersebut.

Menurut Kamus Besar Bahasa Indonesia, pelayanan memiliki tiga makna, yaitu:

1. Perihal atau cara melayani.

2. Usaha melayani kebutuhan orang lain dengan memperoleh imbalan.

3. Kemudahan yang diberikan sehubungan jual beli barang atau jasa.

Pelayanan pada dasarnya dapat didefinisikan sebagai aktivitas seseorang, sekelompok dan/atau organisasi baik langsung maupun tidak langsung untuk memenuhi kebutuhan. Menurut Monir (2013:16), pelayanan adalah proses pemenuhan kebutuhan melalui aktivitas orang lain secara langsung. Sedangkan Menteri Pendayagunaan Aparatur Negara (1993), mengemukakan bahwa pelayanan adalah sebagai bentuk kegiatan pelayanan dalam bentuk barang atau jasa dalam rangka upaya pemenuhan kebutuhan masyarakat. 
Pelayanan publik dapat didefinisikan sebagai segala bentuk jasa pelayanan, baik dalam bentuk barang publik maupun jasa publik yang pada prinsipnya menjadi tanggung jawab dan dilaksanakan oleh instansi pemerintah baik di pusat, daerah, dan lingkungan Badan Usaha Milik Negara (BUMN) atau Badan Usaha Milik Daerah (BUMD), dalam rangka upaya pemenuhan kebutuhan masyarakat maupun dalam rangka pelaksanaan ketentuan perundang-undangan.

Menurut Mahmudi (2005:205-210), pelayanan publik yang harus diberikan oleh pemerintah dapat diklasifikasikan ke dalam dua kategori utama, yaitu: pelayanan kebutuhan dasar dan pelayanan umum yang dijelaskan sebagai berikut:

1. Pelayanan kebutuhan dasar

Pelayanan kebutuhan dasar yang harus diberikan oleh pemerintah terhadap masyarakat meliputi:

a. Kesehatan

Kesehatan merupakan salah satu kebutuhan dasar masyarakat, maka kesehatan adalah hak bagi setiap warga masyarakat yang dilindungi oleh UUD. Setiap negara mengakui bahwa kesehatan menjadi modal terbesar untuk mencapai kesejahteraan. Oleh karena itu, perbaikan pelayanan kesehatan pada dasarnya merupakan suatu investasi sumber daya manusia untuk mencapai masyarakat yang sejahtera.

b. Pendidikan dasar

Pendidikan merupakan suatu bentuk investasi sumber daya manusia. Masa depan suatu bangsa akan sangat di tentukan oleh seberapa besar pengertian pemerintah terhadap pendidikan masyarakatnya. Tingkat pendidikan juga sangat berpengaruh terhadap tingkat kemiskinan karena pendidikan merupakan salah satu komponen utama kemiskinan.

c. Bahan kebutuhan pokok

Dalam penyediaan kebutuhan pokok, pemerintah perlu menjamin stabilitas harga kebutuhan pokok masyarakat dan menjaga ketersediaannya di pasar maupun di gudang dalam bentuk cadangan atau persediaan.

2. Pelayanan umum

Selain pelayanan kebutuhan dasar pemerintah sebagai instansi penyedia pelayanan publik juga harus memberikan pelayanan umum kepada 
masyarakatnya. Pelayanan umum yang harus diberikan kepada masyarakat terbagi menjadi tiga, yaitu :

a. Pelayanan administratif

Pelayanan administratif adalah pelayanan berupa penyediaan berbagai bentuk dokumen yang dibutuhkan oleh publik, misalnya: pembuatan KTP, sertifikat tanah, akta kelahiran, akta kematian, buku pemilik kendaraan bermotor, surat tanda nomor kendaraan bermotor,ijin mendirikan bangunan, dan sebagainya.

b. Pelayanan barang

Pelayanan barang adalah pelayanan yang menghasilkan berbagai bentuk atau jenis barang yang menjadi kebutuhan publik, misalnya : jaringan telepon, penyediaan tenaga listrik, penyediaan air bersih.

c. Pelayanan jasa

Pelayanan jasa adalah pelayanan yang menghasilkan berbagai brntuk jasa yang dibutuhkan publik, misalnya: pendidikan tinggi dan menengah, pemeliharaan kesehatan, penyelenggaraan transportasi, sanitasi lingkungan, persampahan, dan sebagainya.

Kualitas pelayanan merupakan komponen penting yang harus diperhatikan dalam pelayanan publik, istilah kualitas pelayanan publik tentunya tidak dapat dipisahkan dari persepsi tentang kualitas pelayanan. Menurut Sampara (1999) dalam Hardiansyah (2011:35), mengemukakan bahwa kualitas pelayanan adalah pelayanan yang diberikan kepada konsumen sesuai dengan standar pelayanan yang telah dibakukan dalam memberikan layanan sebagai pembakuan pelayanan yang baik.

Menurut Ibrahim (2008:22) dalam Hardiansyah (2011:40), kualitas pelayanan publik merupakan suatu kondisi dinamis yang berhubungan dengan produk, jasa, manusia, proses dan lingkungan dimana penilaian kualitasnya ditentukan pada saat terjadi pemberian pelayanan publik.

Menurut Goetsch dan Davis dalam Hardiyansyah (2011:36), menyatakan bahwa kualitas pelayanan adalah sesuatu yang berhubungan dengan terpenuhinya harapan/kebutuhan pelanggan, dimana pelayanan dikatakan 
berkualitas apabila dapat menyediakan produk dan jasa (pelayanan) sesuai dengan kebutuhan dan harapan pelanggan.

Berdasarkan penjelasan diatas, kami dapat menyimpulkan bahwa kualitas pelayanan publik adalah bentuk totalitas pelayanan yang dilakukan oleh aparatur negara secara maksimal apabila dapat menyediakan produk atau jasa berdasarkan kesesuaian dalam rangka memenuhi kebutuhan dan harapan masyarakat.

B. Dimensi Kualitas Pelayanan Publik

Menurut Zeithaml, Parasuraman dan Berry dalam Pasolong (2011:135) untuk mengetahui kualitas pelayanan yang dirasakan secara nyata oleh konsumen, terdapat indikator ukuran kepuasan konsumen yang terletak pada lima dimensi kualitas pelayanan menurut apa yang dikatakan konsumen. Kelima dimensi tersebut, yaitu:

1. Tangibles (bukti langsung), Kualitas pelayanan berupa sarana fisik perkantoran, komputerisasi administrasi, ruang tunggu, tempat informasi dll.

2. Reliability (kehandalan), Kemampuan dan keandalan untuk menyediakan pelayanan yang terpercaya.

3. Responsiveness (daya tanggap), Kesanggupan untuk membantu dan menyediakan pelayanan secara cepat, tepat dan tanggap terhadap keinginan konsumen.

4. Assurance (jaminan), Kemampuan dan keramahan serta sopan santun pegawai dalam meyakinkan kepercayaan konsumen.

5. Empaty (empati), Sikap tegas, tulus dan penuh perhatian terhadap konsumen.

Sedangkan menurut Garvin dalam Tjiptono dan Diana (2003:27), terdapat delapan dimensi kualitas pelayanan publik, yaitu sebagai berikut:

1. Kinerja (performance), karakteristik operasi pokok dari produk inti.

2. Ciri-ciri atau keistimewaan tambahan (features), yaitu karakteristik sekunder atau pelengkap.

3. Kehandalan (realibility), yaitu kemungkinan kecil akan mengalami kerusakan atau gagal dipakai. 
4. Kesesuaian dengan spesifikasi (corformance to specification), yaitu sejauh mana karakteristik desain dan operasi memenuhi standar-standar yang telah ditetapkan sebelumnya.

5. Daya tahan (durability), berkaitan dengan berapa lama produk tersebut dapat terus dilakukan.

6. Serviceability, meliputi kecepatan, kompetensi, kenyamanan, mudah direparasi, penanganan keluhan yang memuaskan.

7. Estetika, yaitu daya tarik produk terhadap panca indera.

8. Kualitas yang dipersepsikan (perceived quality), yaitu citra dan reputasi produk serta tanggung jawab perusahaan terhadapnya.

Dari beberapa pendapat diatas mengenai tolak ukur kualitas pelayanan publik, maka dalam penelitian ini penulis menggunakan salah satunya yaitu: ukuran kualitas pelayanan publik menurut Zeithhaml-Parasurman-Berry dalam Pasolong (2011:135) dengan lima dimensi kualitas pelayanan publik. Kelima dimensi tersebut adalah tangibles, reliability, responsivess, assurance, emphaty, dan. Alasan peneliti menggunakan teori ini adalah teori ini sudah teruji untuk mengukur kualitas pelayanan selain itu hal ini dilakukan agar peneliti fokus dalam penelitian.

C. Unsur Kualitas Pelayanan Publik

Didalam pelayanan publik, harus mengandung unsur-unsur dasar sebagai berikut:

1. Hak dan kewajiban bagi pemberi pelayanan harus jelas dan diketahui secara pasti oleh masing-masing pihak.

2. Pengaturan setiap bentuk pelayanan harus disesuaikan dengan kondisi kebutuhan dan kemampuan masyarakat untuk membayar berdasarkan ketentuan perundang-undangan yang berlaku dengan tetap berpegang teguh pada efisiensi dan efektivitas.

3. Kualitas, proses dan hasil pelayanan harus diupayakan agar dapat memberi keamanan, kenyamanan dan kepastian hukum yang dapat dipertanggung jawabkan.

4. Apabila pelayanan yang diselenggarakan oleh pemerintah terpaksa harus mahal, maka instansi pemerintah yang bersangkutan berkewajiban memberi peluang kepada masyakaat untuk ikut menyelenggarakannya. 
D. Faktor Kualitas Pelayanan Publik

Menurut Parasuraman, Zeithaml, dan Berry (dalam Tjiptono, 1998:69) yang melalukan penelitian khusus terhadap beberapa jenis pelayanan, mengidentifikasi sepuluh faktor utama yang menentukan kualitas pelayanan publik, yakni :

1. Realibility, yang mencakup konsistensi kerja (performance) dan kemampuan untuk dipercaya (dependability). Hal ini berarti perusahaan memberikan pelayanannya secara tepat sejak awal (right the first time) dan telah memenuhi janji (iklan)nya.

2. Responsiveness, yaitu kemauan atau kesiapan para pegawai untuk memberikan pelayanan yang dibutuhkan pelanggan.

3. Competence, artinya setiap pegawai perusahaan memiliki pengetahuan dan ketrampilan yang dibutuhkan untuk dapat memberikan pelayanan tertentu.

4. Access, yaitu kemudahan untuk dihubungi atau ditemui, yang berarti lokasi fasilitas pelayanan mudah dijangkau, waktu menunggu tidak terlalu lama, saluran komunikasi mudah dihubungi.

5. Courtesy, yaitu sikap sopan santun, respek, perhatian, dan keramahan dari para kontak personal perusahaan

6. Communication, yaitu memberikan informasi yang dapat dipahami pelanggan serta selalu mendengarkan saran dan keluhan pelanggan.

7. Credibility, yaitu jujur dan dapat dipercaya. Disini menyangkut nama dan reputasi perusahaa, karakteristik pribadi, kontak personal, dan interaksi dengan pelanggan.

8. Security, yaitu aman (secara fisik, finansial dan kerahasiaan) dari bahaya, resiko atau keragu-raguan.

9. Understanding/knowing the customer, yaitu upaya untuk memahami kebutuhan pelanggan.

10. Tangible, yaitu segala bukti fisik seperti pegawai, fasilitas, peralatan, tampilan fisik dari pelayanan misalnya kartu kredit plastik.

E. Penilaian Kualitas Pelayanan Publik

Kualitas pelayanan publik bisa dikatakan berkualitas ataupun tidak berkualitas sebenarnya didasarkan pada penilaian dari pelayanan yang diberikan. Menurut Parasuraman dalam Hardiyansyah (2011:92), Penilaian kualitas pelayanan sebagai suatu pertimbangan global atau sikap yang berhubungan dengan 
keungggulan (superiority) dari suatu pelayanan. Penilaian kualitas pelayanan sama dengan sikap individu secara umum terhadap kinerja perusahaan. Selanjutnya, ditambahkan bahwa penilaian kualitas pelayanan adalah tingkat dan arah perbedaan antara harapan dan persepsi pelanggan.

Dalam rangka menilai sejauh mana kualitas pelayanan publik yang diberikan oleh aparatur negara, perlu ada kriteria/faktor kualitas pelayanan publik yang sudah dibahas sebelumnya untuk menunjukkan apakah suatu pelayanan publik yang diberikan dapat dikatakan baik atau buruk, berkualitas atau tidak. Organisasi pelayanan publik mempunyai ciri publik accountability, dimana setiap warga negara mempunyai hak untuk mengevaluasi kualitas pelayanan yang mereka terima. Kualitas pelayanan akan sangat sulit untuk dinilai tanpa melibatkan peran masyarakat sebagai penerima pelayanan dari aparat pelaksana pelayanan.

Berdasarkan uraian di atas jelas menunjukkan bahwa pelayanan yang diberikan oleh aparatur negara sesungguhnya tidak terlepas dari perilaku internal birokrasi itu sendiri.

\section{F. Manfaat Kualitas Pelayanan Publik}

Kualitas pelayanan publik juga dapat diketahui dengan cara membandingkan persepsi para pelanggan (masyarakat) atas pelayanan yang sesungguhnya mereka inginkan, apabila pelayanan dalam prakteknya yang diterima oleh masyaraka sama dengan harapan atau keinginan mereka maka pelayanan tersebut dikatakan sudah memuaskan. Terciptanya kepuasan pelanggan dapat memberikan berbagai manfaat, seperti:

1. Hubungan antara pelanggan dan pemberi layanan menjadi harmonis, sehingga memberikan dasar yang baik bagi terciptanya loyalitas pelanggan.

2. Membentuk suatu rekomendasi dari mulut ke mulut (word of mouth) yang menguntungkan bagi pemberi layanan.

3. Reputasi pelayanan publik akan semakin baik dimata pelanggan.

4. Sebagai upaya peningkatan kualitas pelayanan pemerintah kepada masyarakat dan sebagai acuan pengembangan penyusunan standar pelayanan. Penyedia layanan, pelanggan atau stakeholder dalam kegiatan pelayanan akan memiliki acuan tentang bentuk, alasan, waktu, tempat dan proses pelayanan yang seharusnya. 


\section{BAB III}

\section{PERMASALAHAN DAN PEMBAHASAN}

\section{A. Permasalahan}

Pelayanan publik merupakan hak dasar bagi warga negara yang harus dipenuhi oleh negara. Hal ini dilakukan karena pelayanan publik merupakan bagian yang tak terpisahkan dari kewajiban negara untuk mensejahterakan rakyatnya. Pelayanan publik bukan semata-mata hanya menyiapkan instrument bagi berjalannya birokrasi untuk menggugurkan kewajiban negara, melainkan lebih dari itu, bahwa pelayanan publik merupakan esensi dasar bagi terwujudnya keadilan sosial.

Buruknya pelayanan publik yang terjadi selama ini karena tidak adanya paradigma yang jelas dalam penyelenggaraan pelayanan publik. Kinerja pelayanan yang diberikan oleh birokrasi yang ada di indonesia masih cukup kuat watak mengabdi kepada kekuasaan (state oriented) dibandingkan kepada publik (publik oriented). Sehingga wajah birokrasi indonesia kesan otoriter-rentenya cukup kuat. Situasi birokrasi yang demikian tentu berdampak terhadap pelaksanaan pelayanan publik yang diberikan. Pelayanan birokrasi akan terpola dengan model caring calture masih jauh dari kesan demokratis dan berkualitas yang nampak adalah kesan diskriminatif. Konstitusi sudah menjelaskan bahwa paradigma dari fungsi negara adalah melindungi rakyatnya dari berbagai macam persoalan. Secara esensial, konsep melindungi yang tersirat dalam konstitusi, dilihat bentuk praksisnya yaitu adanya pelayanan yang harus disediakan oleh pemerintah yang berkualitas dan tidak diskriminatif. Memastikan adanya akses bagi rakyat untuk mendapatkan pelayanan dari pemerintah baik secara ekonomi, politik, sosial maupun budaya.

Saat ini banyak sekali fakta pelayanan publik yang diberikan oleh pemerintah selalu tidak memuaskan, bahkan cenderung selalu diskriminatif dan dengan tampilan wajah yang buruk. Kenyataan yang terjadi selama ini hampir selalu paradox, antara semangat untuk melakukan perubahan dalam tata pemerintahan yang baik (good governance) dengan fakta dilapangan (mayoritas). 
Banyak fakta menunjukan jeleknya pelayanan yang diberikan oleh institusiinstitusi negara/pemerintahan. Contoh kecil misalnya tentang hak asas pendidikan (the right to education) banyak yang tidak terpenuhi dan menimbulkan masalah. Masalah tersebut adalah tidak terpenuhinya akses terhadap sekolah, tenaga pengajar dan fasilitas pendidikan formal dan non formal. Banyak anak putus sekolah dan menjadi pekerja anak. Disamping itu biaya pendidikan yang sangat mahal (fungsi sosialnya hilang dan fungsin bisnisnya yang menemukan) dan banyak persoalan berkenaan dengan kualitas pendidikan.

Kualitas pelayanan publik di indonesia belum memberikan kepuasan bagi masyarakat sebagai pengguna layanan. Andrinof Charniago (2006) mengamati berbagai persoalan pelayanan publik di indonesia. Hasil pengamatannya memperihatkan berbagai persoalan tersebut diantaranya:

1. Hanya sebagian kecil dari keseluruhan instansi yang wajib menyediakan pelayanan yang memiliki prosedur yang jelas.

2. Banyak instansi penanggungjawab dan pemberi pelayanan yang tidak memiliki prosedur yang jelas dalam menyediakan pelayanan.

3. Tidak banyaknya perubahan dalam waktu sekian tahun juga mengindikasikan tidak ada system monitoring, evaluasi, dan perencaaan yang baik yang dilakukan oleh instansi-instansi penanggungjawab dan penyedia pelayanan publik.

Tugas negara yang tercantum dalam berbagai peraturan perundang-undangan jelas tergambar bahwa negara ini lahir untuk memberikan pelayanan kepada rakyatnya. Tetapi dalam kenyataannya pelayanan publik di negara kita itu belum berjalan dengan baik. Contoh kecil dari masalah pelayanan publik di indonesia yaitu:

1. Paradigma pelayanan publik dan mentalitas aparat.

Aturan dan regulasi yang ada sebenarnya sudah meneguhkan tanggung jawab negara dalam memberi pelayanan, namun ironisnya banyak di temukannya kasus yang menggambarkan buruknya pelayanan publik di indonesia. Dan belum berubahnya sikap dan paradigma dari aparatur negara dalam pemberian pelayanan yang masih rules-driven atau berdasar perintah atau petunjuk atasan, namun bukan kepuasan masyarakat. 
2. Kualitas pelayanan tidak memadai dan masih diskriminatif.

Dimana jaminan terhadap pemenuhan hak-hak dasar masyarakat yang tanpa diskriminasi belum diberikan dengan kualitas yang memadai. Selain itu pelayanan publik yang disediakan umumnya terbatas, misalnya jumlah, kualitas tenaga, fasilitas dan sarana tidak memadai dan tidak merata. Umunya ini disebabkan oleh keterbatasan SDM serta alokasi anggaran yang kurang memadai dalam APBD. Disejumlah daerah, APBD lebih banyak dihabiskan untuk kegiatan rutin dibandingkan kegiatan pembangunan.

3. Belum adanya regulasi yang memadai.

Regulasi yang ada belum mampu meyakinkan bahwa kewajiban negara semestinya di iringi dengan kemampuan memberi layanan yang terbaik kepada warganya. Selain itu, partisipasi masyarakat dalam proses pemberian layanan belum optimal, meski terdapat perangkat yang dapat mendukung upaya itu.

Ada beberapa hal yang mempengaruhi pelayanan publik:

1. Kebijakan atau keputusan politik yang diambil oleh pemerintah.

Kebijakan yang diambil seringkali tidak memihak pada kepentingan masyarakat, dan cenderung merugikan rakyat, para pengambil kebijakan lebih mementingan orang-orang yang terdekat serta golongan mereka. Seringkali kebijakan yang diambil tidak memberikan jaminan maupun kepentingan kepada rakyat. Tidak adanya undang-undang yang memberikan jaminan kepada rakyat yang dirugikan oleh negara serta jaminan perlindungan rakyat melakukan pengaduan. Peraturan yang ada hanya mengatur kewajiban rakyat saja tanpa mencantumkan kewajiban negara serta sanksinya bagi mereka yang lalai melaksanakan tugasnya. Pada saat pemberi layanan lalai atau gagal saat menjalankan tugas rakyat tidak berdaya untuk melakukan protes.

2. Manajemen dari pelaksanaan pelayanan publik.

Selama ini pelaksanaan pelayanan publik lebih bersifat state oriented tidak publik oriented. Dimana kepentingan negara lebih di priyoritaskan, segala yang menyangkut negara akan mendapatkan porsi yang lebih daripada dibandingkan dengan kepentingan masyarakat. Sebagai contoh adalah pemerintah memberikan perhatian lebih terhadap pemberian di aceh yang terancam memisahkan diri dari $\mathrm{Rl}$, dibandingkan dengan masalahmasalah keutahan social masyarakat seperti konflik di Maluku, Poso maupun 
tempat-tempat lain yang sampai saat ini masih berlangsung. Kewajiban warga negara lebih ditekankan dari pada kewajiban negara terhadap warganya. Warga negara diharuskan membayar pajak, bahkan di kenai denda jika terlambat untuk membayar, akan tetapi tidak mendapatkan jaminan yang memadai dari negara, misalnya tidak ada jaminan kesehatan, pendidikan ataupun jaminan lainnya. Manajemen pelayanan seringkali dirasakan lambat dan sangat birokratis. Hal tersebut dikarenakan aparatur pelaksana tidak bisa mengambil keputusan sendiri tanpa adanya persetujuan dari atasan mereka.

3. Latar belakang kultur layanan.

Disini kultur pelayanan yang berkembang masih feudal. Pemberi layanan masih menggunakan kultur peninggalan nenek moyang yang sebenarnya sudah tidak relevan lagi apabila diterapkan saat ini. Pada masa kerajaan dengan memberikan upeti, melayani dan melakukan apa saja yang menjadi kehendak raja serta para penjabatnya.

\section{B. Pemecahan Masalah}

Sebagai pelayan publik, para aparatur negara seharusnya melayani setiap kepentingan masyarakat tidak terkecuali. Karena seringkali aparatur negara hanya mendahulukan orang-orang yang mempunyai "uang" untuk membeli pelayanan yang maksimal, seharusnya para aparatur negara tersebut bersikap adil dalam melayani setiap orang baik itu kaya ataupun miskin. Selain sikap ketidakadilan, mental para aparatur negara seringkali memaknai dirinya sebagai "Raja".

Hal ini sebabkan karena mereka tidak memamhami posisi dirinya sebagainya pelayan masyarakat. Seharusnya untuk menghapuskan mentalitas pelayanan publik yang mementongkan diri sendiri maka solusinya adalah sebagai berikut:

1. Meningkatkan kualitas pendidikan pada aparatur negara diharapkan mereka akan lebih mengerti akan arti sesungguhnya mengenai pelayanan publik.

2. Membangun komitmen bersama setiap komponen bangsa, terutama dalam masyarakat, partai politik, LSM untuk segera mengakhiri praktik pelayanan publik yang tidak sesuai dengan apa yang diharapkan. Pelayanan publik harus adanya reformasi agar perubahan dalam pelayanan publik tersebut dapat dirasakan oleh masyarakat. 
3. Membangun kesadaran publik untuk sama-sama mengontrol jalannya pelayanan publik.

Dengan cara itulah pelayanan publik dapat di tingkatkan kualitasnya karena masyarakat sama-sama mengawasi jalannya pelayanan publik tersebut. Contohnya bila masyarakat tidak puas akan pelayanan suatu instansi pemerintah, maka masyarakat dapat melaporkan atau mengadukannya kepada lembaga ombudsman. Oleh karenanya tingkat mental masyarakat untuk tidak terlalu tunduk kepada aparatur negara karena pada dasarnya aparatur negara tersebut di gajih secar tidak langsung oleh masyarakat melalui pajak yang dibayar oleh masyarakat.

Dalam menjalankan pelayanan publik agar efektif dan efisien serta adil harus disertai dengan peraturan yang tegas. Karena peraturan yang tegas dapat membuat seorang aparatur negara akan bersikap disiplin dan profesional. Salah satunya adalah dengan menindak tegas aparatur negara yang bersikap diskriminatif terhadap orang miskin dalam hal pelayanan. Dapat Salah satu contohnya dapat dikenakan sanksi untuk tidak dinaikkan pangkatnya dalam jangka beberapa waktu. Sehingga para aparatur tersebut akan berpikir ulang bilamana mereka melakukan tindakan yang salah tersebut.

Memperlakukan penghargaan (reward) juga harus diterapkan pada aparatur negara yang menjalankan tugasnya dengan baik. Salah satunya dengan memberikan bonus bagi aparatur yang menjalankan tugasnya dengan baik. Sebagai pedoman dalam melaksanakn setiap kegiatan yang meliputi pelayanan publik peraturan perundang-undangan seharusnya berpihak kepada rakyat sebagai konsumen dari pelayanan publik itu. Dalam membuat peraturan mengenai pelayan publik para legislator harus memahami akan kondisi masyarakat yang menginginkan sebuah pelayanan prima seperti halnya pelayanan yang dilakukan oleh perusahaan swasta. Para anggota dapat selaku membuat undang-undang harus turun kepada masyarakat agar mengetahui kondisi riil permasalahan mengenai pelayanan publik sehingga dengan hal itu mereka akan tau dimana letak msalahnya dan hal tersebut dapat menjadi acuan bagi mereka dalam hal membuat undang-undang. 


\section{BAB IV}

\section{KESIMPULAN}

Kualitas pelayanan publik adalah bentuk totalitas pelayanan yang dilakukan oleh aparatur negara secara maksimal sesuai dengan aturan pokok dan tata cara yang ditentukan dan dapat menyediakan produk atau jasa berdasarkan kesesuaian dalam rangka memenuhi kepuasan, kebutuhan dan harapan masyarakat sebagai penerima pelayanan.

Kualitas pelayanan publik dapat diketahui dengan cara membandingkan persepsi para pelanggan (masyarakat) atas pelayanan yang sesungguhnya mereka inginkan. Apabila pelayanan pada prakteknya dapat diterima oleh masyarakat sama dengan harapan atau keinginan mereka, maka pelanggan tersebut dikatakan sudah memuaskan. Terciptanya kepuasan pelanggan dapat memberikan berbagai manfaat, diantaranya hubungan antara pelanggan dan pemberi layanan menjadi harmonis, sehingga memberikan dasar yang baik bagi terciptanya loyalitas pelanggan, membentuk suatu rekomendasi dari mulut ke mulut (word of mouth) yang menguntungkan bagi pemberi layanan, reputasi yang semakin baik di mata pelanggan, serta penyedia layanan, pelanggan atau stakeholder dalam kegiatan pelayanan akan memiliki acuan tentang bentuk, alasan, waktu, tempat dan proses pelayanan yang seharusnya.

Masalah kualitas pelayanan publik antara lain, yaitu:

1. Paradigma pelayanan publik dan mentalitas apparat.

2. Kualitas pelayanan yang tidak memadai dan masih diskriminatif.

3. Belum adanya regulasi yang memadai.

Solusi masalah kualitas pelayanan publik:

1. Menghapus mentalitas pelayanan publik yang mementingkan diri sendiri.

2. Menerapkan aturan yang tegas dalam pelaksanaan pelayanan publik.

3. Revisi perundang-undangan.

4. Membangun komitmen bersama setiap komponen bangsa untuk segera mengakhiri praktik pelayanan publik yang tidak sesuai dengan apa yang diharapkan. 


\section{KEPUSTAKAAN}

1. Undang-Undang Republik Indonesia Nomor 25 Tahun 2009

2. MicheelLi. Manajemen Kualitas Pelayanan [Aplikasi]. Tersedia di SlideShare

3. Rudi Rinaldi. 2012. Analisis Kualitas Pelayanan Publik. [Internet]. Tersedia di: https://ojs.uma.ac.id/index.php/adminpublik/article/view/945/955

4. Fuji Setiawati Anjani. 2015. Kualitas Pelayanan Publik Dalam Sistem Administrasi Negara Republik Indonesia [Internet]. Terseda di: http://peripanda.blogspot.com/2015/03/kualitas-pelayanan-publik-dalamsistem.html

5. [Internet]. Tersedia di: http://eprints.umpo.ac.id/2637/2/BAB\%20l.pdf

6. file:///C:/Users/KRISNA/Downloads/TUGAS\%20adm\%20publik.pdf 